\title{
Behavior of Reinforced Concrete Slabs Cast with Light Weight Self Compacting Concrete
}

\author{
Khaled M. Heiza ${ }^{*}$; Fatma M. Eid ${ }^{\dagger}$; Taha Masoud ${ }^{\ddagger}$
}

\begin{abstract}
Lightweight self compacting concrete (LWSCC) is one of the latest innovations in concrete technology. This new type of concrete was developed to offer enhanced workability and durability due to its self-consolidation ability. Similar to normal self-consolidating concrete (SCC), these special fresh properties allow (LWSCC) to penetrate through formwork with complex geometry as well as through highly-congested reinforcing. Hence, (LWSCC) provides a better quality in the construction of the structural members with reduced labor. In addition, (LWSCC) also has a further impact on the construction cost by reducing the total dead load of the structural members up to $25 \%$, and requiring less maintenance than a similar steel structure. (LWSCC) can achieve better strength and durability while offering excellent workability, and its mechanical properties are in general either competitive or superior to those in conventional lightweight concrete. This research was conducted to evaluate the roll of "Light Expand clay Aggregate (LECA)" in the manufacture of (LWSCC). By specific gravity factor method, six different mixes of (LWSCC) were cast and tested to find out the values of slump flow, G-ring, and compressive strength. Based on the results obtained, the best mix was selected to study the effect of the reinforcement ratio on the behavior of (LWSCC) one way slabs. The investigation examines also the behavior of the (LWSCC) one way slabs exposed to fire. The results demonstrated that the addition of (LECA) is possible to manufacture a structural (LWSCC) with low density, high self-consolidating, and with acceptance resistance to fire.
\end{abstract}

Keywords: LECA, Light weight self-compacting concrete, One way slabs.

\section{Introduction}

Self-compacting concrete (or SCC) is a relatively recent development in concrete technology; Developed in Japan in the late 1980's by Okamura [1]. The (SCC) as the name suggested, does not require vibration to achieve full compaction. It is essentially a highly flowable yet stable concrete that is easily spread into place and fills formwork without any consolidation and without undergoing significant segregation. Segregation resistance combined with high fluidity result in consolidation entirely due to the concrete's own weight [2].

Lightweight self-compacting concrete (LWSCC) is expected to provide high workability without segregation and high durability with reduced weight. The success to production of high quality (LWSCC) depends on the type of the coarse aggregates. Expanded clay (LECA) and other light weight aggregates such as: expanded shale, pumice, slate, perlite, bottom ash etc.

\footnotetext{
Professor of Reinforced Concrete Structures and bridges, Faculty of Engineering, Menoufia University, Egypt; khheiza@gmail.com

$\dagger$ Ass. Professor, Civil Engineering Department, Faculty of Engineering, Menoufia University, Egypt; fatma_elzahraa2002@yahoo.com

* Master student, Civil Engineering Department, Faculty of Engineering, Menoufia University, Egypt; Engtaha_1990@yahoo.com
} 
have been successfully used in the production of lightweight concretes (LWCs) over the decades [34]. (LECA) is a ceramic material produced by expanding and vitrifying select clay's, in a rotary kiln. The use of expanded clay aggregate with other quality supplementary cementing materials (such as fly ash and silica fume) can provide highly workable and durable ( LWSCCs).

Use of these aggregates has contributed to the sustainable development by conserving energy, maximizing structural efficiency and increasing the service life of structural lightweight concrete (LWC). (LWSCC) is capable of filling up the formwork and encapsulate reinforcement by its selfweight without the need for additional compaction or external vibration. It has excellent segregation resistance, high flowability and passing ability at fresh state as well as better mechanical and durability properties in the hardened state [5].

\section{Research Program}

This research was conducted in three phases: 1-Phase (I): Focused on the experimental study of the fresh and hardened properties of (LWSCC) mixes. Six concrete mixtures were designed. Three key mix design parameters namely water $(\mathrm{w})$ to binder $(\mathrm{b})$ ratio $(\mathrm{w} / \mathrm{b})(0.28-0.35)$, dosage of high range water reducing admixtures (HRWRA) (0.3-1.2 \% by total content of binder) and total binder content (B) $(410-510 \mathrm{~kg} / \mathrm{m} 3)$ were selected to study the influence on the properties of (LWSCC). The tested (LWSCC) properties were, slump flow, V-funnel flow time, J-ring flow diameter/height difference, unit weight and compressive strength. 2-Phase (II): Based on the results obtained, the best mix which achieved the properties of light weight concrete and self-compacting concrete was selected for further investigation. By the standard mix we study the effect of changing reinforcement ratio of one way slabs reinforced by welded wire mesh with variable diameter of wire. 3-Phase (III): Investigate the effect of exposing to fire on the light weight self-compacting one way slabs.

\section{Materials}

\subsection{Cement}

Portland cement type I (CEMI42.5N), provided by the Suze Cement Co., meeting the requirement of E.S. 7417/2001 was used.

\subsection{LECA}

The coarse lightweight aggregate used in this study was locally produced from expanded clay type (LECA) from national cement company. The maximum nominal size of (LECA) was $15 \mathrm{~mm}$. The sieve analysis of (LECA) is given in Table (1). In this study, the dry (LECA) was pre-soaked in water for 48 hours before mixing in concrete until steady weight of LECA was achieved, to ensure that all voids inside (LECA) particles are fully filled with water. The physical of coarse aggregate are given in Table (2).

Table (1): Sieve analysis of (LECA).

\begin{tabular}{l|l|l|l|l|l}
\hline \hline Sieve size $(\mathrm{mm})$ & 19 & 16 & 9.5 & 4.75 & 2.36 \\
\hline$\%$ & 100 & 98 & 79 & 30 & 7 \\
\hline \hline
\end{tabular}


Table (2): Physical and mechanical properties of (LECA).

\begin{tabular}{c|c|c|c}
\hline \hline Description & Water absorption: $\%$ & Specific gravity & Unit weight $\left(\mathrm{kg} / \mathrm{m}^{3}\right)$ \\
\hline LECA & 18.2 & 1.08 & 667 \\
\hline \hline
\end{tabular}

\subsection{Fine Aggregates}

Natural siliceous sand from El-khatatba was used as a fine aggregate.

\subsection{Fly Ash}

Fly ash complies with chemical and physical requirements of American specification [ASTM C618], Europe specification [EN450].

\subsection{Silica Fume}

Micro silica (silica fume) is by-product resulting from industry of ferro silicon alloys. The product is a rich silicon dioxide powder where the average particles size is around 0.1 micrometers. Mechanical and physical properties are given in Table (3).

Table (3): Typical physical and chemical properties of fly ash.

\begin{tabular}{l|l}
\hline \hline Physical properties & Value \\
\hline \hline Colors & Light gray \\
\hline Specific gravity & 2.2 \\
\hline Specific surface area & $8 \mathrm{~m} / \mathrm{gm}$ \\
\hline $\mathrm{PH}$ & 1.2 \\
\hline Chemical analysis & Value \\
\hline Silicon $(\mathrm{SiO} 2)$ & 53.0 \\
\hline Aluminum $(\mathrm{Al2O} 3)$ & 34.0 \\
\hline Iron $(\mathrm{Fe} 2 \mathrm{O} 3)$ & 3.5 \\
\hline Manganese $(\mathrm{Mn} 2 \mathrm{O} 3)$ & 0.2 \\
\hline Calcium $(\mathrm{CaO})$ & 4.5 \\
\hline Magnesium $(\mathrm{MgO})$ & 1.5 \\
\hline Titanium $(\mathrm{TiO} 2)$ & 0.6 \\
\hline Sulphur $(\mathrm{SO} 3)$ & 0.3 \\
\hline \hline
\end{tabular}

\subsection{Viscosity Agent}

Sika viscocrete 3425 was used as viscosity enhancing agent (VEA). It contains a polycarboxylic based copolymer-based mixture and modified cellulose product to achieve the dual action effect of high-range water reducer and viscosity-modifying admixture, respectively.it meets the requirements for super plasticizers according to swiss specification [ SIA 162(2989)], EUROPE specification [EN934-2] , and American specification [ ASTM- C-494 type G and F ). Mechanical and physical properties are given in Table (4). 
Table (4): Typical properties of viscocrete 3425.

\begin{tabular}{l|l}
\hline \hline Properties & Value \\
\hline Appearance & Clear liquid \\
\hline Density & $1.08 \mathrm{~kg} / \mathrm{It}$ (ASTM C494) \\
\hline PH Value & 4.0 \\
\hline Solid content & $40 \%$ by weight \\
\hline Chloride content & Zero \\
\hline \hline
\end{tabular}

\subsection{Reinforcing Steel}

This type of mesh is made of steel wires with diameter and size of mesh as shown in Table (5) The proof stress is equal to $400 \mathrm{~N} / \mathrm{mm}^{2}$ and its ultimate strength is $600 \mathrm{~N} / \mathrm{mm}^{2}$, while its modulus of elasticity equal to $170 \mathrm{KN} / \mathrm{mm}^{2}$.

Table (5): Properties of wire mesh.

\begin{tabular}{c|c|c|c|c}
\hline \hline $\begin{array}{c}\text { Diameter } \\
(\mathrm{mm})\end{array}$ & spacing $(\mathrm{mm})$ & $\begin{array}{c}\text { No. of wires } \\
/ \mathrm{m}^{2}\end{array}$ & $\begin{array}{c}\text { wire weight } \\
(\mathrm{kg} / \mathrm{m})\end{array}$ & $\begin{array}{c}\text { Weight of mesh } \\
\left(\mathrm{kg} / \mathrm{m}^{2}\right)\end{array}$ \\
\hline 3 & $30 \times 30$ & $34 \times 2$ & 0.0555 & 3.778 \\
\hline 4 & $40 \times 40$ & $25 \times 2$ & 0.0986 & 4.938 \\
\hline 5 & $50 \times 50$ & $20 \times 2$ & 0.1541 & 6.173 \\
\hline \hline
\end{tabular}

\section{Concrete Mix Design}

Six mixes of (LWSCC) were designed using the specific gravity factor method $[11,12]$.Table (6) shows the constituents of each mix , All aggregate types used in this study were weighted on a saturated-surface-dry (SSD) basis, to achieve good moisture control in the concrete mixes. The constituent materials were mixed in a pan mixer with a capacity of $0.08 \mathrm{~m}^{3}$ and a mixing speed of 50 $\mathrm{rev} / \mathrm{min}$ at ambient temperatures of about $\left(25 \mathrm{C}^{\circ}\right)$. The super plasticizer (SP) was separately added into the concrete after about $1 \mathrm{~min}$ of mixing. Mixing was continued for another 2 min before the mixture was left at rest for approximately 3 min.

Table (6): The constituents of all mixes.

\begin{tabular}{l|l|l|l|l|l|l}
\hline Mix No. & $\mathrm{C}_{1}$ & $\mathrm{C}_{2}$ & $\mathrm{C}_{3}$ & $\mathrm{C}_{4}$ & $\mathrm{C}_{5}$ & $\mathrm{C}_{6}$ \\
\hline W/c & 0.35 & 0.32 & 0.32 & 0.3 & 0.3 & 0.28 \\
\hline Cement(Kg) & 382 & 325 & 390 & 382 & 400 & 382 \\
\hline Fly ash (Kg) & 76 & 62 & 72 & 76 & 72 & 76 \\
\hline Silica fume ( Kg) & 51 & 23 & 27 & 51 & 27 & 51 \\
\hline Water (Liter) & 180 & 130 & 160 & 153 & 160 & 143 \\
\hline SP (Liter) & 3.8 & 1.2 & 6 & 5.1 & 1.5 & 3.8 \\
\hline Sand (Kg) & 790 & 840 & 825 & 900 & 830 & 870 \\
\hline LECA (Kg) & 390 & 474 & 412 & 450 & 415 & 410 \\
\hline \hline
\end{tabular}

* viscocrete 3425 . 


\section{Casting of Test Specimens}

a- Cubes with $10 \mathrm{~cm}$ side length were used for determination of the compressive strength of light weight self-compacting concrete.

b- Using the mixture (C4) for six slabs casted using wooden mould with dimension (1000 mm * $400 \mathrm{~mm} * 50 \mathrm{~mm}$ ) as shown in Fig.(1).The thickness of the slabs were kept constant, The thickness of mesh layers and their combinations were varied in order to get higher strength. Table (7) shows the properties of reinforced slabs.

Table (7): Properties of reinforced slabs.

\begin{tabular}{l|l|l|l|l}
\hline \hline Slab No. & $\begin{array}{l}\text { Dimensions of slab } \\
(\mathrm{mm})\end{array}$ & Reinforcement & $\begin{array}{l}\text { Mesh size } \\
(\mathrm{mm})\end{array}$ & Test conditions \\
\hline $\mathrm{S}_{1}$ & $1000 * 400 * 50$ & welded mesh thick $3 \mathrm{~mm}$ & $30 * 30$ & normal state \\
\hline $\mathrm{S}_{2}$ & $1000 * 400 * 50$ & welded mesh thick $4 \mathrm{~mm}$ & $40 * 40$ & normal state \\
\hline$S_{3}$ & $1000 * 400 * 50$ & welded mesh thick $5 \mathrm{~mm}$ & $50 * 50$ & normal state \\
\hline$S_{1 \mathrm{~F}}$ & $1000 * 400 * 50$ & welded mesh thick $3 \mathrm{~mm}$ & $30 * 30$ & subjected to fire \\
\hline$S_{2 \mathrm{~F}}$ & $1000 * 400 * 50$ & welded mesh thick $4 \mathrm{~mm}$ & $40 * 40$ & subjected to fire \\
\hline$S_{3 \mathrm{~F}}$ & $1000 * 400 * 50$ & welded mesh thick $5 \mathrm{~mm}$ & $50 * 50$ & subjected to fire \\
\hline \hline
\end{tabular}

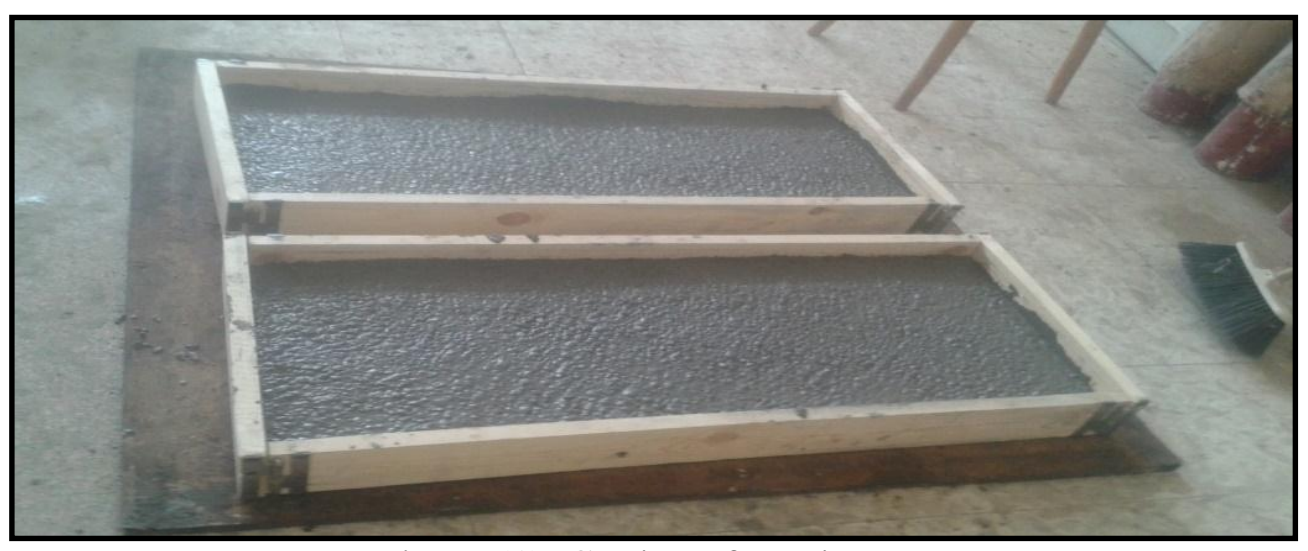

Figure (1): Casting of specimens.

\section{Results and Discussion}

\subsection{Fresh Characteristics of (LWSCC)}

Immediately after the mixing, the value of slump flow, and J-ring were determined, the values showed in Table (8) [14] .The slump flow test was used to evaluate the free deformability and flowability of (LWSCC) in the absence of obstruction. The result of slump flow for mixtures showed that an increase in the w/b from (0.3 to 0.35) significantly increased the slump flow However, at the same (HRWRA\% ), also a great positive effect of the coupled parameters (w/b and HRWRA) in increasing slump flow. The slump flow test for (LWSCC) is shown in Fig. (2). 


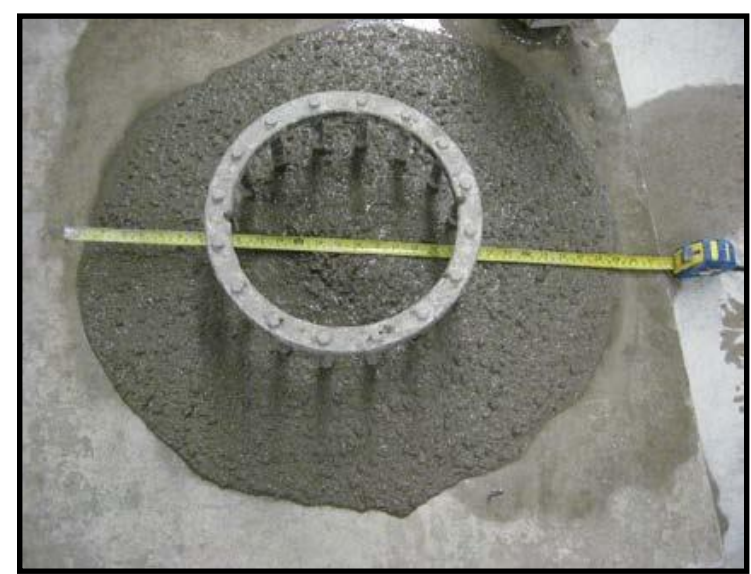

A) J-ring test

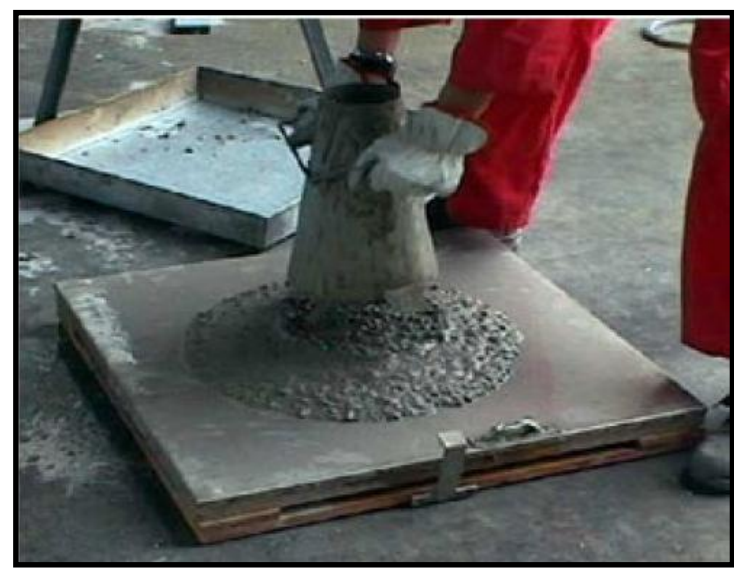

B) Slump test.

Figure (2): Slump flow and J-ring test

Table (8): Fresh properties of mixes.

\begin{tabular}{c|c|c}
\hline \hline Mix No. & Slump flow $(\mathrm{mm})$ & J - Ring height different, ( mm) \\
\hline $\mathrm{C}_{1}$ & 750 & 5 \\
\hline $\mathrm{C}_{2}$ & 650 & 8 \\
\hline $\mathrm{C}_{3}$ & 700 & 6 \\
\hline $\mathrm{C}_{4}$ & 690 & 6 \\
\hline $\mathrm{C}_{5}$ & 550 & 10 \\
\hline $\mathrm{C}_{6}$ & 450 & 12 \\
\hline
\end{tabular}

\subsection{Hardened characteristics of (LWSCC)}

Six different concrete mixes were investigated to study the compressive strength of light weight selfcompacted concrete at 7 , and 28 days age. The tests were carried out on $10 * 10 * 10 \mathrm{~cm}$ concrete cubes according to ASTM C39-86. Table (9) shows the compressive strength and the unite weight of the investigated mixes. The highest compressive strength was developed by Mix (C4).The results cleared that compressive strength increase with decrease of $(\mathrm{w} / \mathrm{c})$ ratio and increased with increase of cementinous materials. All mixtures unit weight less than $2000 \mathrm{~kg} / \mathrm{m} 3$ so that it can be light weight concrete. The best mixture which achieve the requirements of light weight self-compacting concrete (LWSCC) with best strength is mixture (C4).

Table (9): Compressive strength and unit weight of (LWSCC) mixes.

\begin{tabular}{l|c|c|c|c}
\hline \hline \multirow{2}{*}{$\begin{array}{l}\text { Mix } \\
\text { No. }\end{array}$} & \multicolumn{2}{|c|}{$\begin{array}{c}\text { Compressive strength } \\
(\mathrm{kg} / \mathrm{cm} 2)\end{array}$} & \multicolumn{2}{c}{ Unit weight $\left(\mathrm{kg} / \mathrm{m}^{3}\right)$} \\
\cline { 2 - 5 } & 7 - day & 28 -day & Fresh & Air dry \\
\hline $\mathrm{C}_{1}$ & 162 & 190 & 1820 & 1790 \\
\hline $\mathrm{C}_{2}$ & 130 & 153 & 1850 & 1810 \\
\hline $\mathrm{C}_{3}$ & 155 & 186 & 1880 & 1830 \\
\hline $\mathrm{C}_{4}$ & 167 & 227 & 1910 & 1865 \\
\hline $\mathrm{C}_{5}$ & 152 & 184 & 1860 & 1800 \\
\hline $\mathrm{C}_{6}$ & 172 & 200 & 1900 & 1850 \\
\hline \hline
\end{tabular}




\subsection{Test setup of slabs}

Special flexure loading frame was exclusively fabricated for testing the slabs and the details of the test setup is shown in Fig. (3). In order to test the slabs on a four point loading, Loading was applied manually through a hydraulic jacking (50 ton capacity), the load was given through the jack in small increments and the deflection of the slab was recorded up to failure using dial gauges in the middle point of slab.
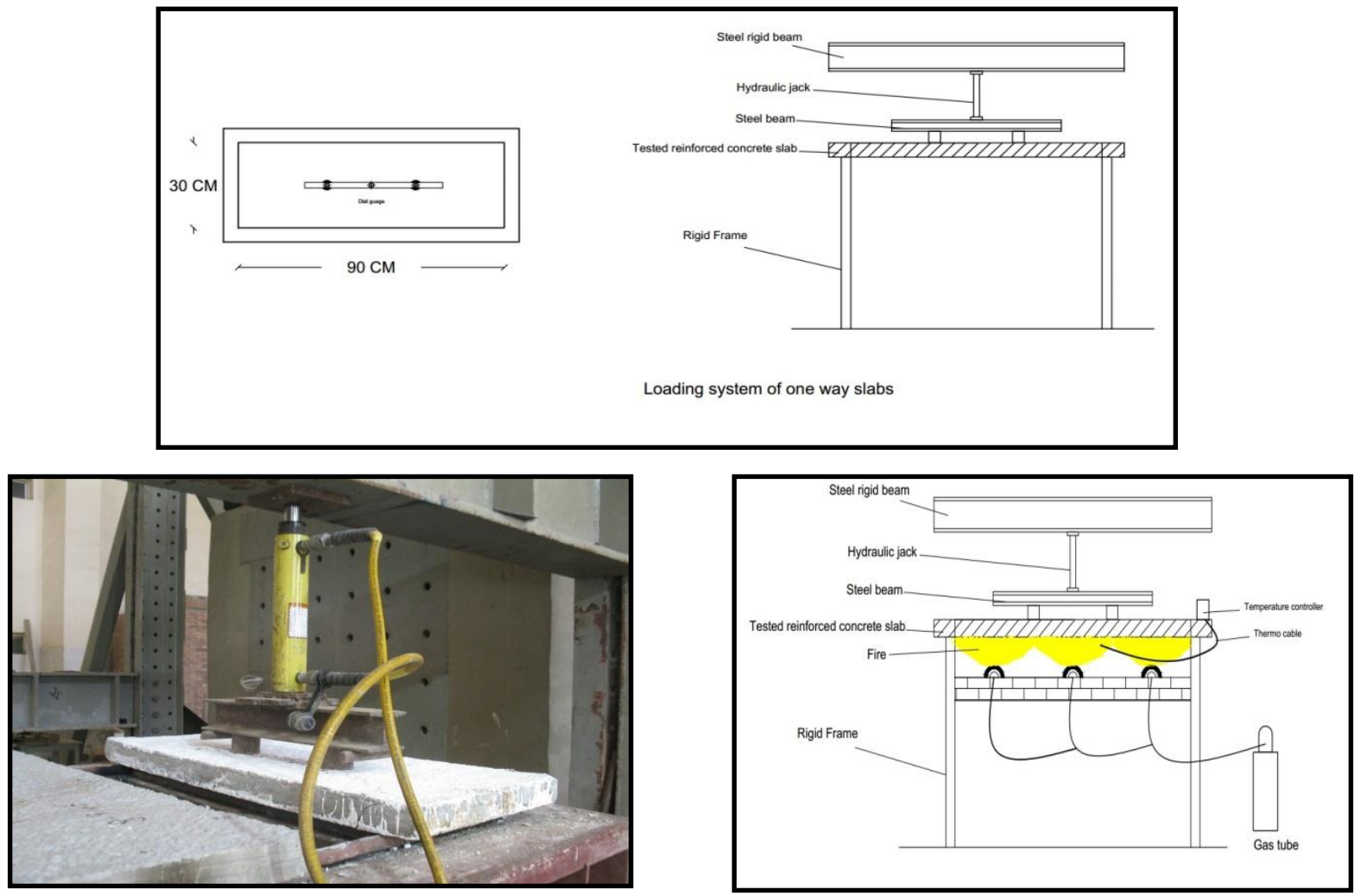

Figure (3): Test set-up.

\subsection{Result of the slab}

A total of 3 specimens were tested in this investigation on four point loading tests and the results of the experimental tests carried out are analyzed including the flexural loads and deflection. As shown in Figs. (4 and 5), slab (S3) reinforced with wire mesh 5mm diameter recorded the highest value of ultimate load due to bigger diameter and pitch spacing ( $50 \mathrm{mmx} 50 \mathrm{~mm}$ ) while slab (S1) reinforced with wire mesh $3 \mathrm{~mm}$ diameter obtained the lowest value of ultimate load due to their smaller diameter and pitch spacing (30mm x 30mm). The failure loads of slab (S2), and (S3) increased by $42 \%$ and $23 \%$ respectively compared to slab (S1). For one way slabs the first crack load for slab (S2 and S3) increased by $50 \%$ and $125 \%$ respectively compared to the first crack load of slab (S1). The failure load after subjected to fire decreased by ( $20 \%, 22 \%$, and $26 \%$ ) for slabs ( S1F, S2F , and S3F ) respectively compared to the slabs (S1,S2, and S3) as shown in Fig.(5). Figures (6, 7, and 8) show cracks pattern of all slabs. As shown in Figures $(9,10$, and 11), it can be concluded that, for the slabs (S1, S2, S3, S1F, $\mathrm{S} 2 \mathrm{~F}$, and $\mathrm{S} 3 \mathrm{~F})$ at the same chosen load (2.5 ton), the slabs (S1F, S2F, and S3F) deflections were increased at the mid span by about $(42 \%, 58 \%$, and 10\%) in comparison with the control slabs (S1, $\mathrm{S} 2$, and $\mathrm{S} 3$ ) respectively. 


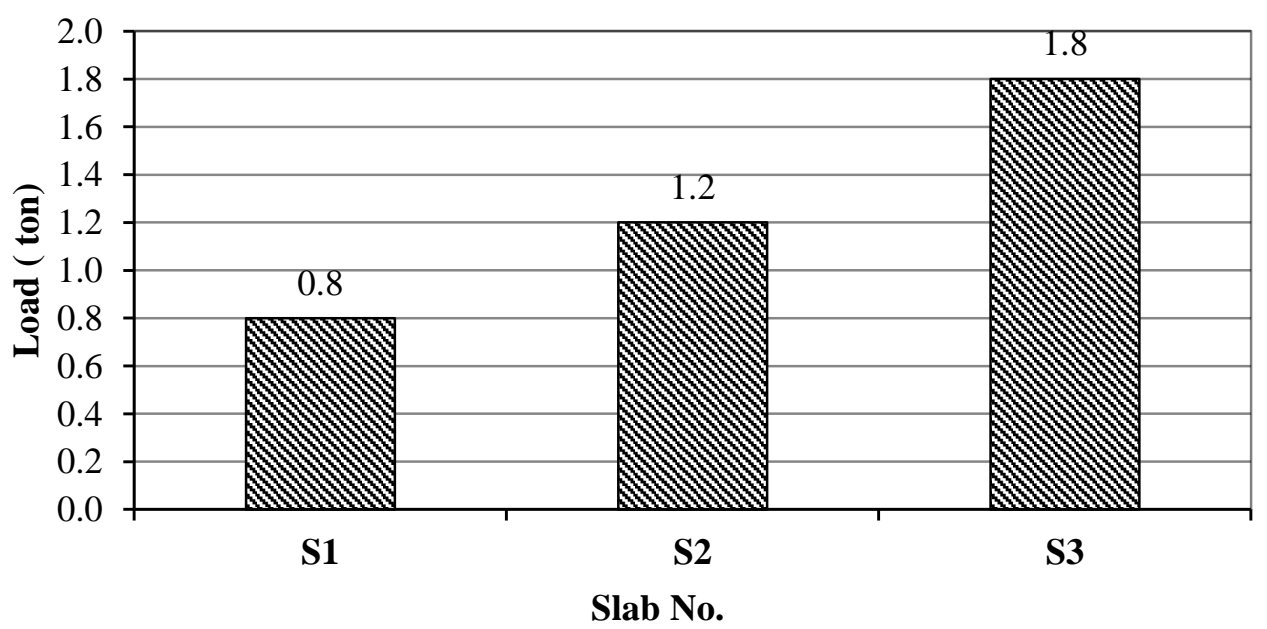

Figure (4): The cracking loads of slabs.

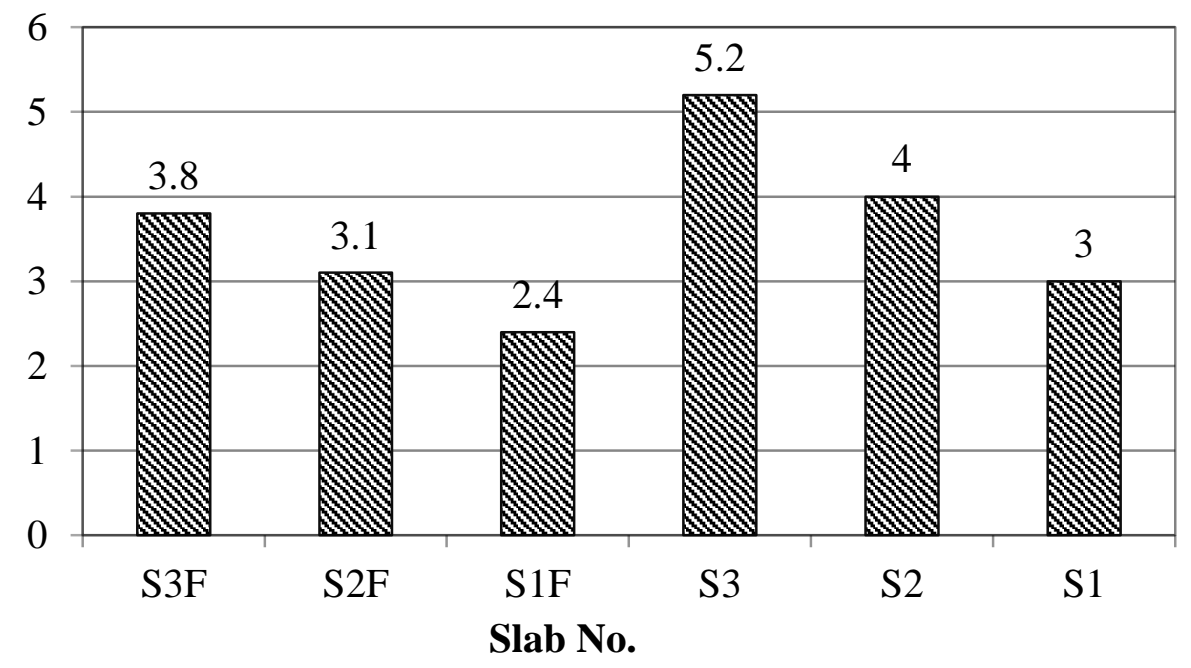

Figure (5): Comparison between the ultimate loads of all slabs.
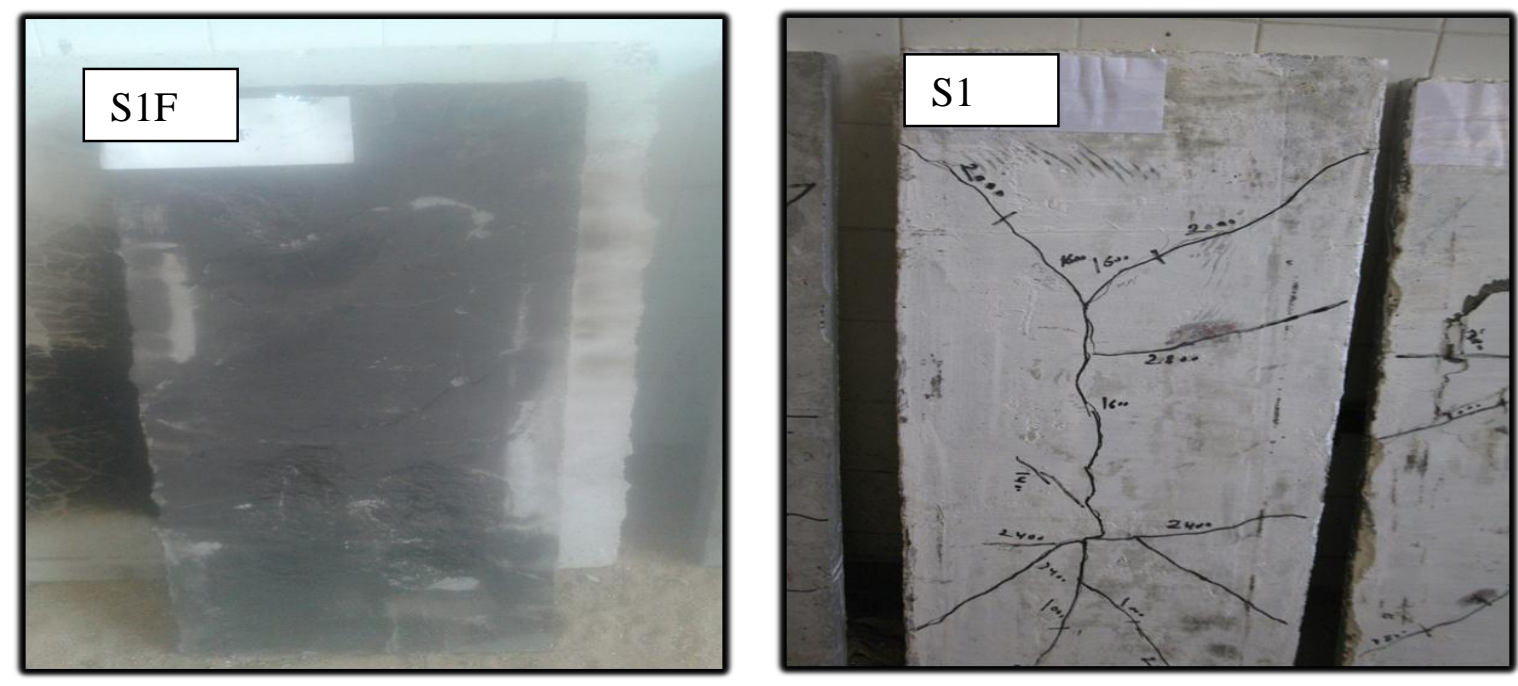

Figure (6): Crack patterns of slabs (S1, and S1F). 

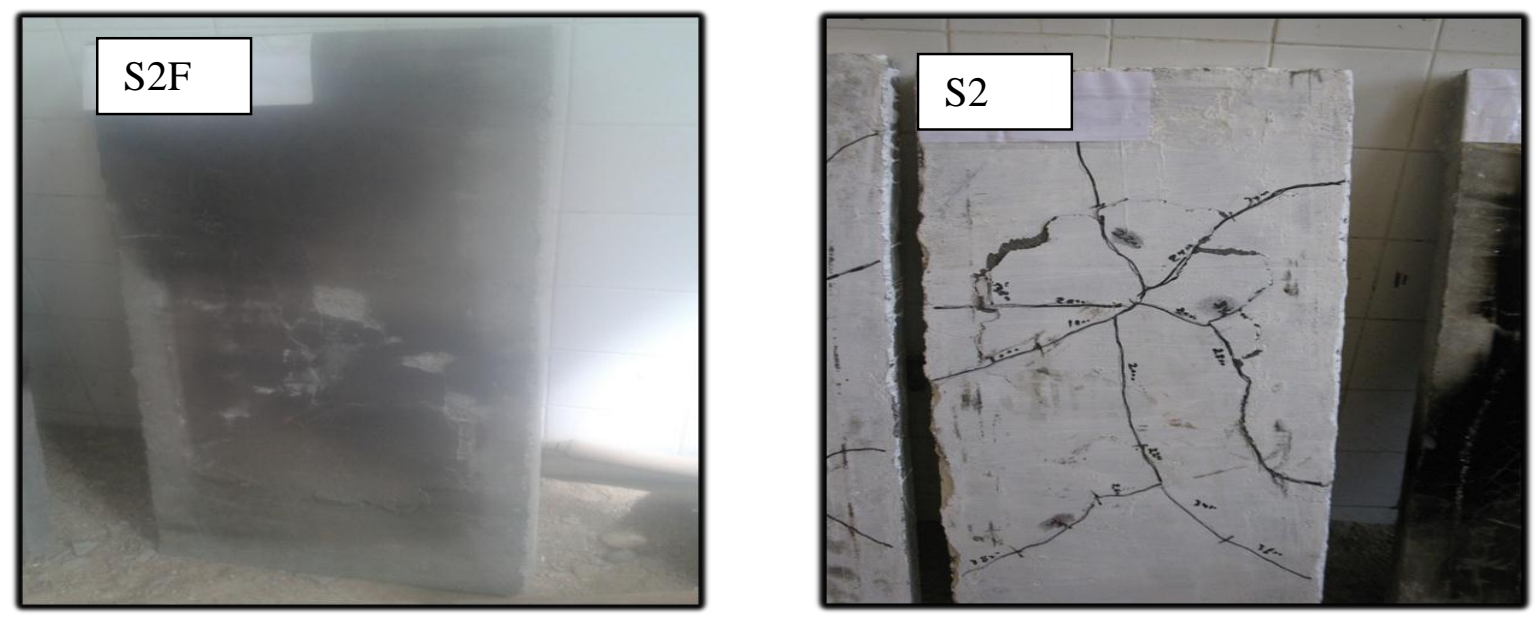

Figure (7): Crack patterns of slabs (S2, and S2F).
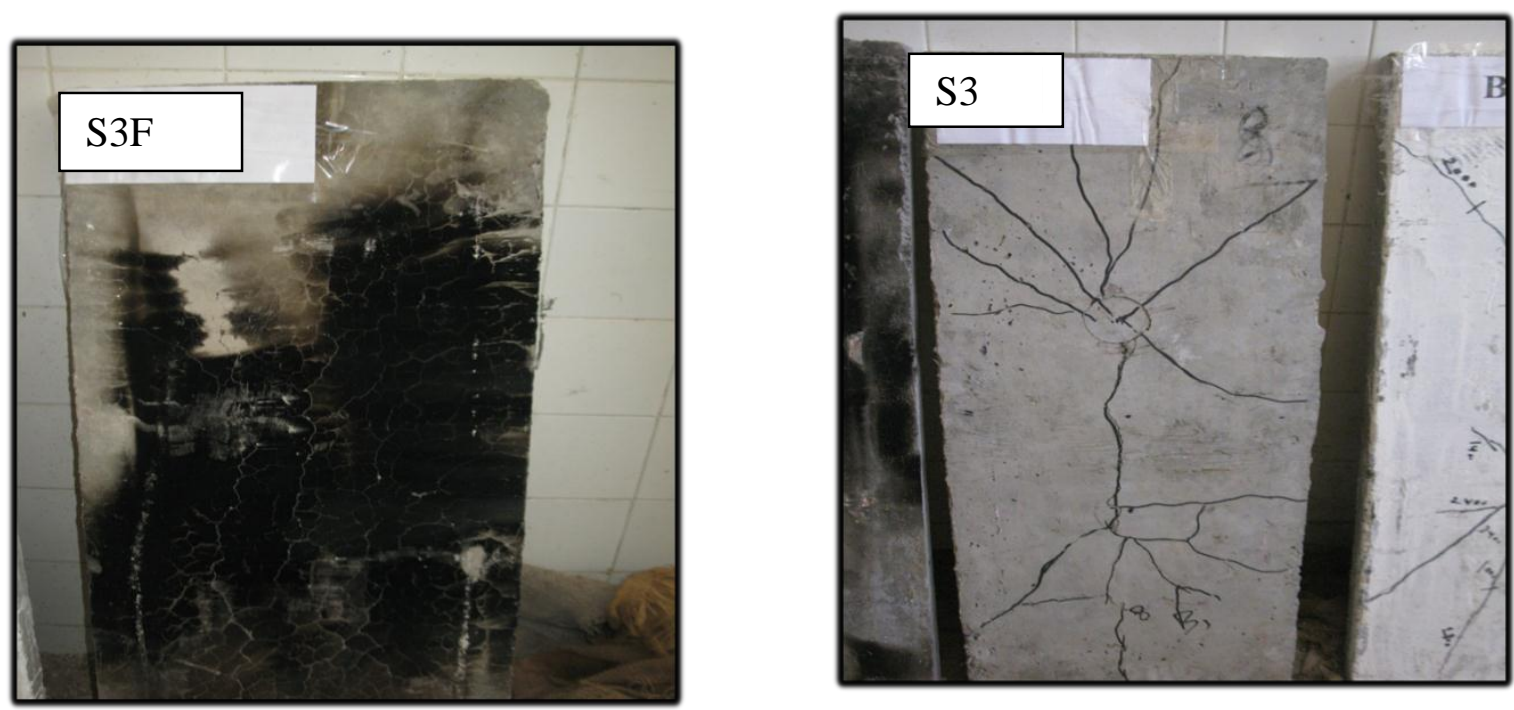

Figure (8): Crack patterns of slabs (S3, and S3F). 


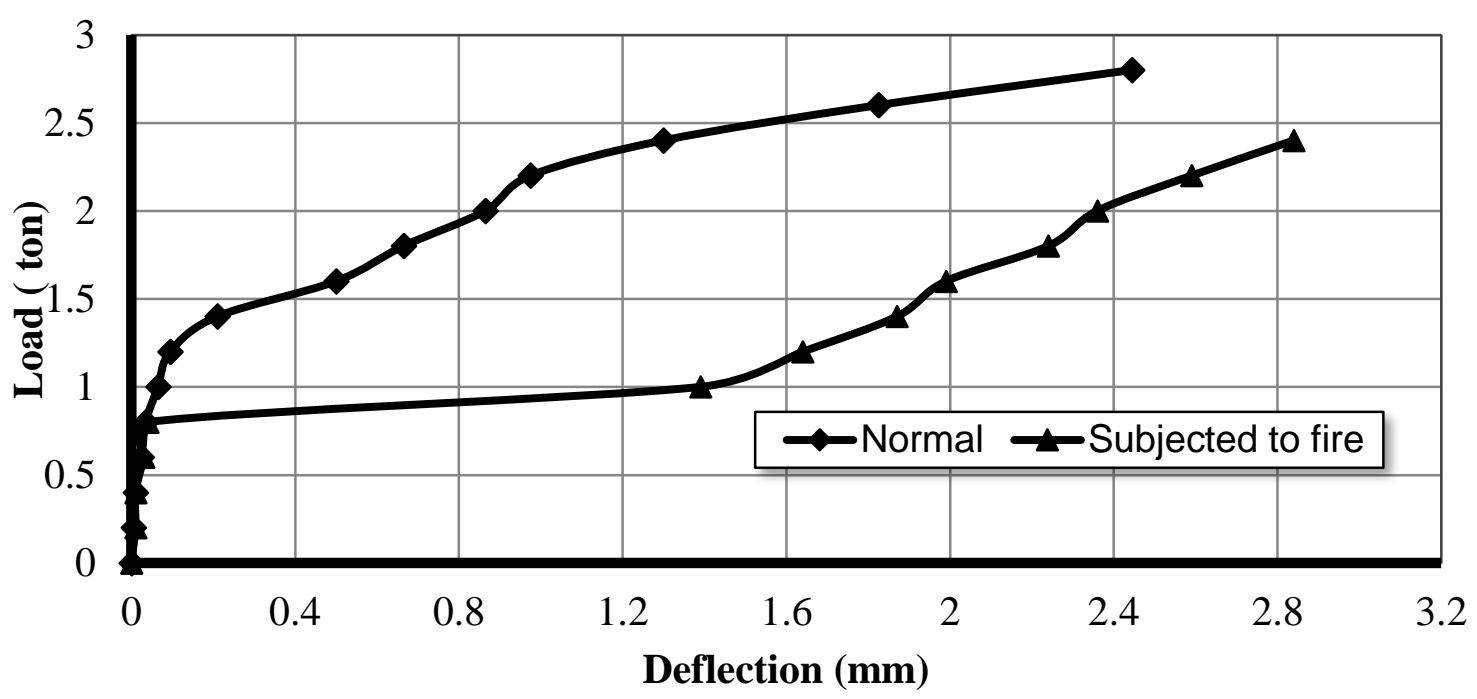

Figure (9): Load - deflection curve of slabs (S1, and S1F).

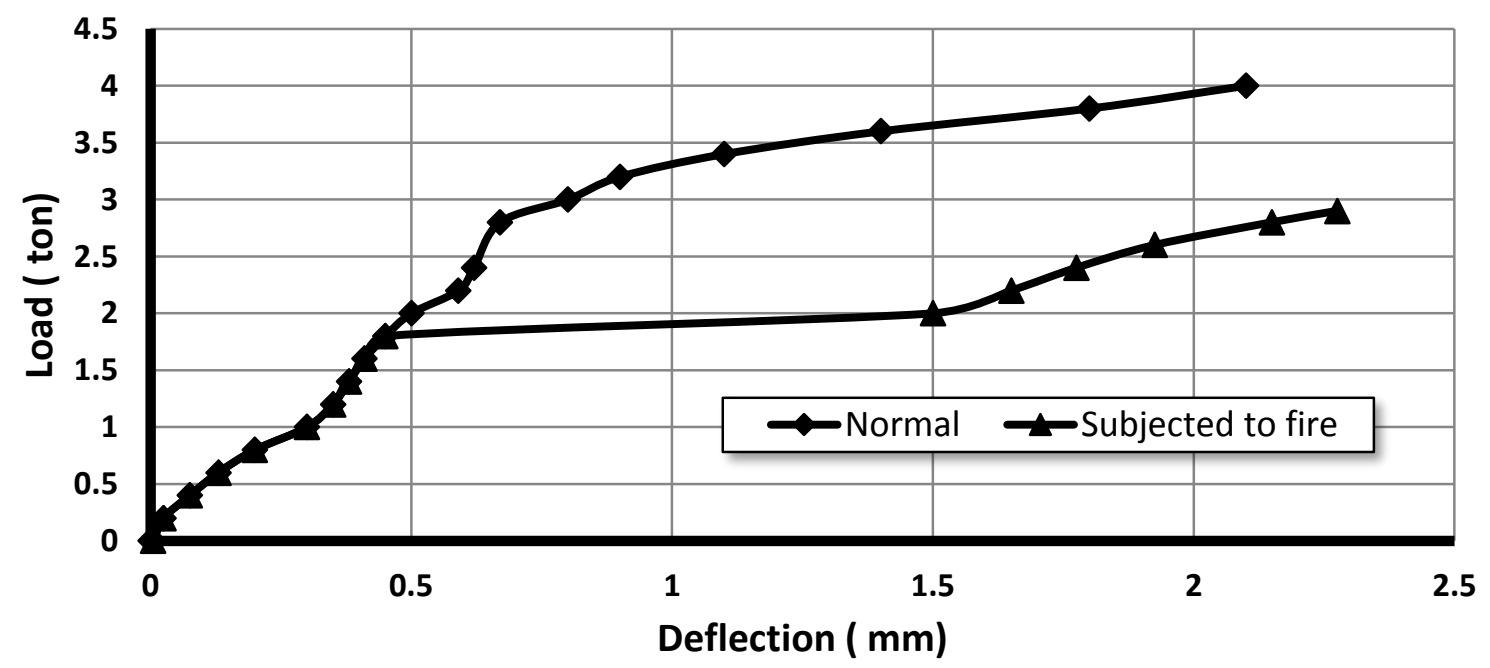

Figure (10): Load - deflection curve of slabs (S2, and S2F). 


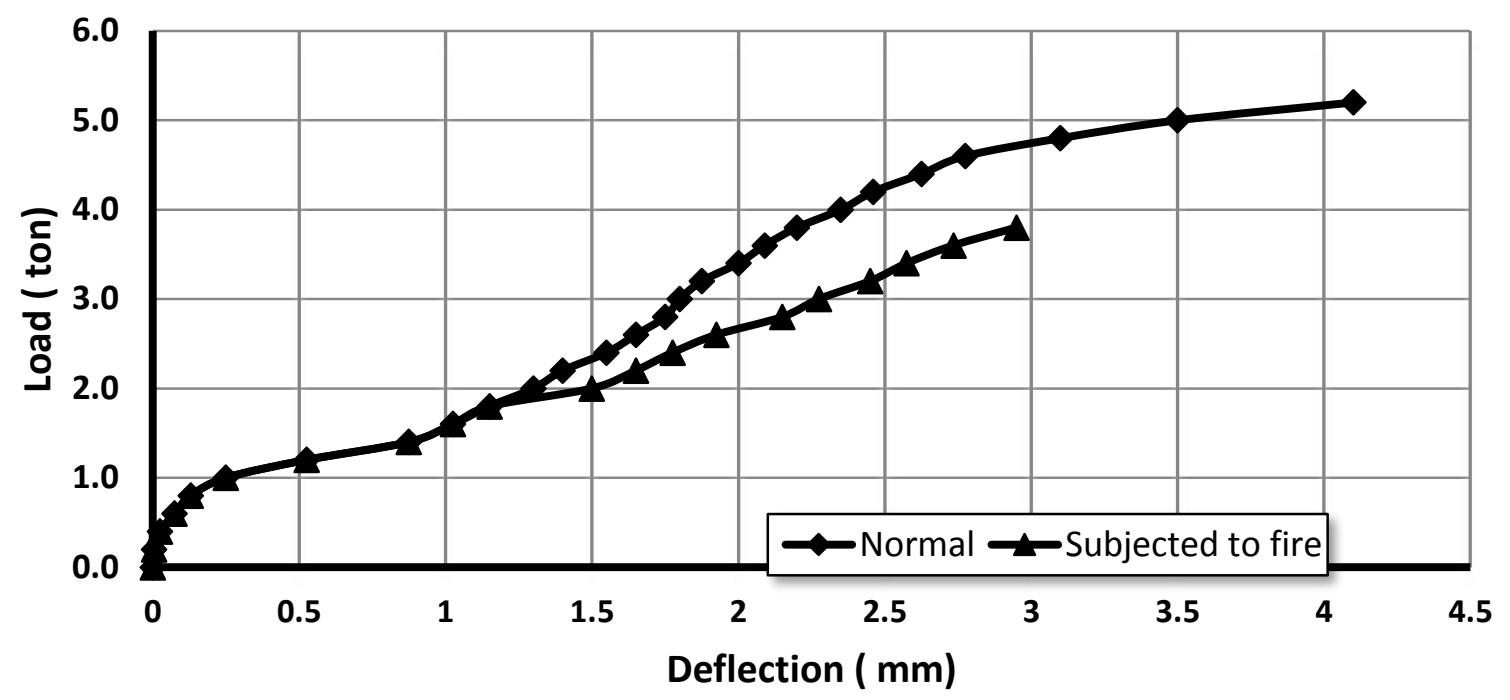

Figure (11): Load - deflection curve of slabs (S3, and S3F).

\section{Conclusions}

Based on the results and observations of the experimental study presented, the following conclusions could be drawn as follows:

1-It is possible to manufacture a structural (LWSCC) with low density and high self-consolidating characteristics (flowability, deformability, self-compatibility and stability) using expanded clay aggregate (LECA).

2- Pre-wetted (LECA) gives higher stability of rheological behavior of fresh concrete and foaming of cement matrix is easier to control.

3- First cracking and ultimate loads depend on thickness of reinforcing mesh layers used in the slab.

4- This research work showed that the failure loads of slab (S2), and (S3) increased by 42\%, 23\% respectively compared to slab (S1). Hence with increase in thickness of layers of wire mesh we can increase the performance of slabs.

5 - The (water/binder) ratio (w/b) has significant influence on the overall performance of (LWSCCs), including fresh and hardened properties. In terms of fresh properties. The passing ability and filling capacity increase with the increases of $(w / b)$. The segregation resistance decreases with increase of $(\mathrm{w} / \mathrm{b})$.

6- Cracking load to ultimate load ratio of the slab with steel reinforcement are nearly constant.

7 - During testing it was observed that the slab did not break into pieces after failure, instead the cracks were found to widen. This is because the wire mesh holds together the cement mortar instead of breaking and falling off. By observing the cracks it was inferred that the slab with layer of wire mesh with $4 \mathrm{~mm}$ thickness has more crack pattern compared to slab with layer of wire mesh $5 \mathrm{~mm}$ thickness. Hence with increase in thickness of layers of wire mesh we can increase the performance of slabs. One way slabs were studied while the dimensions are kept constant. 


\section{References}

[1] T. Sonia, R. Subashini, "Experimental Investigation on Mechanical Properties of Light Weight Concrete Using Leca", International Journal of Science and Research (IJSR) .ISSN 2319-7064, (2017).

[2] S.Sundari, S.Sukumar "Study on Filler Slab Using Self Compacting Concrete with Terracotta Pots as Filler" International Journal of Advanced Engineering Technology (2016) E-ISSN 0976-3945.

[3] R. Gopi, V. Revathi, D. Kanagaraj, "Light Expanded Clay Aggregate and Fly Ash Aggregate As Self Curing Agents In Self Compacting Concrete", Asian journal of civil engineering, Vol. 16, No. 7 (2016), p.p 1025-1035.

[4] Hossain, K. M. A. (2004). "Properties of volcanic pumice based cement and lightweight concrete". Cement and Concrete Research, 34(2), 283-291.

[5] Fragoulis, D., Stamatakis, M. G., Chaniotakis, E., \& Columbus, G. (2004). Characterization of lightweight aggregates produced with clayey diatomite rocks originating from Greece. Materials Characterization, 53(2-4), 307-316.

[6] Topc ,U., I. B., \& Uygunog `lu, T. (2010). "Effect of aggregate type on properties of hardened self-consolidating lightweight concrete (SCLC)". Construction and Building Materials, 24(7), 1286-1295.

[7] ESCSI. (2004)." Expanded clay, shale and slate, a world of application" (p. 5) Worldwide, Salt Lake City, UT, Publication No. 9349.

[8] Bai Y, Ibrahim R and Muhammed Basheer PA (2004) "Properties of lightweight concrete manufactured with fly ash, furnace bottom ash, and slag. Proceedings of an International Workshop on Sustainable Development and Concrete Technology, Beijing, pp. 77-88.

[9] Chia KS and Zhang MH (2004) "Effect of chemical admixtures on rheological parameters and stability of fresh lightweight aggregate concrete". Magazine of Concrete Research 56(8): 46547.

[10] ACI (American Concrete Institute) (1981) ACI 211.2-81" Standard Practice for Selecting Proportions of Structural Lightweight Concrete". ACI, Detroit.

[11] EFNARC, (2005), "The European Guidelines for Self Compacting Concrete", Specification, Production and Use The Self-Compacting Concrete European Project Group, pp. 63.

[12] Eid, F.M., "Behavior of Reinforced Concrete Elements Strengthened with Fiber Reinforced Polymers under Different Loading Conditions", Ph.D. Thesis, Menoufiya University, Faculty of Engineering, Shebin El-Kom, Egypt, 2007. 